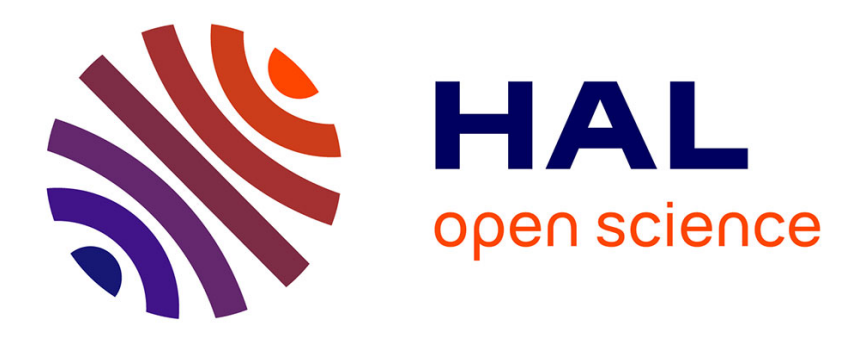

\title{
Neuroplasticity of the visual cortex: in sickness and in health
}

\author{
Laura Baroncelli, Claudia Lunghi
}

\section{To cite this version:}

Laura Baroncelli, Claudia Lunghi. Neuroplasticity of the visual cortex: in sickness and in health. Experimental Neurology, 2020, 335, pp.113515. 10.1016/j.expneurol.2020.113515 . hal-03064893

\section{HAL Id: hal-03064893 \\ https://hal.science/hal-03064893}

Submitted on 28 Sep 2021

HAL is a multi-disciplinary open access archive for the deposit and dissemination of scientific research documents, whether they are published or not. The documents may come from teaching and research institutions in France or abroad, or from public or private research centers.
L'archive ouverte pluridisciplinaire HAL, est destinée au dépôt et à la diffusion de documents scientifiques de niveau recherche, publiés ou non, émanant des établissements d'enseignement et de recherche français ou étrangers, des laboratoires publics ou privés. 
Neuroplasticity of the visual cortex: in sickness and in health

Laura Baroncelli ${ }^{1,2^{*}}$, Claudia Lunghi ${ }^{3}$

[1] Institute of Neuroscience, National Research Council (CNR), I-56124, Pisa, Italy.

[2] Department of Developmental Neuroscience, IRCCS Stella Maris Foundation, I56128, Pisa, Italy.

[3] Laboratoire des systèmes perceptifs, Département d'études cognitives, École normale supérieure, PSL University, CNRS, 75005 Paris, France.

*To whom correspondence should be addressed: baroncelli@in.cnr.it.

Corresponding author:

Laura Baroncelli

Institute of Neuroscience, National Research Council (CNR)

via Moruzzi 1, Pisa I-56124, Italy.

Email: baroncelli@in.cnr.it

Tel: +390 503153199 Fax: +390503153220 


\begin{abstract}
Brain plasticity refers to the ability of synaptic connections to adapt their function and structure in response to experience, including environmental changes, sensory deprivation and injuries. Plasticity is a distinctive, but not exclusive, property of the developing nervous system. This review introduces the concept of neuroplasticity and describes classic paradigms to illustrate cellular and molecular mechanisms underlying synapse modifiability. Then, we summarize a growing number of studies showing that the adult cerebral cortex retains a significant degree of plasticity highlighting how the identification of strategies to enhance the plastic potential of the adult brain could pave the way for the development of novel therapeutic approaches aimed at treating amblyopia and other neurodevelopmental disorders. Finally, we analyze how the visual system adjusts to neurodegenerative conditions leading to blindness and we discuss the crucial role of spared plasticity in the visual system for sight recovery.
\end{abstract}

Keywords: neural plasticity, visual cortex, monocular deprivation, amblyopia, Retinitis Pigmentosa, Macular Degeneration, glaucoma 


\section{Introduction}

Our brain receives a continuous flow of stimulation from the external environment, which builds our ability to perceive stimuli, make movements, think, learn, remember and plan behavioural strategies. Experience, indeed, can functionally and structurally mould synaptic connections of the nervous system. Overall, these processes are known as neural plasticity and represent a distinctive, but not exclusive, feature of the developing nervous system: genes guide early stages of brain development and the initial formation of synaptic junctions, while interactions with the environment are needed for tuning the maturation of circuits in a proper and individual-specific way (Berardi et al., 2015; Takesian and Hensch, 2013). Neural plasticity underlies a selective phenomenon that involves the strengthening of some synaptic connections and the elimination of others, resulting in the final wiring of circuits. The time window during which experience plays an essential role in shaping the developing nervous system is known as a sensitive or critical period (CP). The maturation of different brain functions occurs in different moments in time, therefore, there is not a single $\mathrm{CP}$ in the brain development, but a different CP for each function (Berardi et al., 2000; Hensch, 2004).

The visual system has historically been the gold standard for investigating the mechanisms of neural plasticity, since visual experience can be easily manipulated and the consequences of such manipulations on the visual cortex can be measured at the physiological, anatomical and molecular level. In particular, the protocol of monocular deprivation (MD), with the occlusion of one eye causing a significant imbalance in the visual sensory drive, has been studied as a paradigmatic experimental model of plasticity. The classic experiments of Hubel and Wiesel in kittens have shown that MD causes an irreversible weakening of the visual functions of the closed eye and a dramatic change in the primary visual cortex organization. The deprived eye, in fact, loses much of its ability to activate the visual cortex, resulting in a reduction of neurons that respond preferentially to the stimulation of that eye and the parallel increase of the cells activated by the open eye (Hensch and Quinlan, 2018; Wiesel and Hubel, 1965, 1963). This phenomenon is called ocular dominance (OD) plasticity and has been acknowledged in all mammals, but plasticity extends to visual features beyond cortical OD and involves subcortical regions as well (Hooks and Chen, 2020). The effectiveness of MD is more pronounced during the pertaining $\mathrm{CP}$ of development, which is of different length depending on the 
species studied (Berardi et al., 2000; Horton and Hocking, 1997; Issa et al., 1999; Lehmann and Löwel, 2008). It is worth noting, however, that some forms of plasticity persist throughout life and can be boosted by different manipulations in the adult brain (Hooks and Chen, 2020, 2007; Ribic, 2020).

\section{Hebbian and homeostatic mechanisms: plasticity in action}

The effects of sensory deprivation can be explained in terms of the Hebb principle: this model of synapse modifiability postulates that the strengthening of connections is due to the temporal coincidence between the discharge activities of the presynaptic and postsynaptic neurons (Hebb, 1949). The fibers driven by the open eye have a rich activity, modulated by visual experience, which effectively depolarizes cortical neurons, while the fibers guided by the deprived eye have a very reduced activity (essentially constituted by the spontaneous activity of the retina and thalamus), which is unrelated to that of the other group and is not sufficient to exceed the activation threshold of the cortex. This ensures that an appropriate temporal coincidence between afferent and cortical activity takes place only at the level of the synapses that convey the information entering from the open eye, resulting in the consequent enhancement of the latter at the expense of deprived eye (Bear, 2003). The involvement of homosynaptic plasticity phenomena, defined as long term potentiation (LTP) and long-term depression (LTD), in this process has been repeatedly suggested (Bear, 2003; Cooke and Bear, 2010; Kirkwood and Bear, 1994).

However, this form of bidirectional functional plasticity is likely to work in tandem with other processes across visual cortical circuits to store information (Cooke and Bear, 2010; Kaneko and Stryker, 2017; McCoy et al., 2009). Hebbian plasticity co-operates, indeed, with another form of plasticity, called homeostatic plasticity, to refine neural circuits of the primary visual cortex in response to altered visual experience (Kaneko and Stryker, 2017; Turrigiano, 2017). Homeostatic plasticity refers to a number of cell autonomous and non-cell autonomous feedback mechanisms maintaining network excitability within a dynamic range allowing effective information transmission (Kaneko and Stryker, 2017; Turrigiano, 2017). Homeostatic plasticity acts through synaptic scaling, adjusting the weight of excitatory and inhibitory synapses, and the modification of intrinsic excitability of neuronal circuits (Turrigiano, 2017). In the framework of OD plasticity, the reduction 
of cortical activity due to the loss of responses driven by the deprived eye might stimulate the homeostatic upregulation of remaining inputs contributing to the dramatic increase in the weight of the open eye after 2-3 days of MD, but also to the boost of deprived-eye responses surprisingly observed at the same time (Kaneko and Stryker, 2017). Moreover, there are other forms of plasticity falling outside the strict Hebbian/homeostatic dualism, and including for example heterosynaptic plasticity and gating mechanisms, that could play a role in the expression of visual cortex plasticity (Kaneko and Stryker, 2017; Turrigiano, 2017).

Given its peculiar characteristics, the NMDA glutamate receptor plays a key role in detecting the correlation between presynaptic and postsynaptic activity, and the pharmacological manipulation of these receptors alters the effects of MD with mechanisms varying according to the cortical layer (Crozier et al., 2007). A requirement of excitatory synapses in triggering the effects of sensory deprivation (Daw et al., 2004; Dölen and Bear, 2008; Heynen et al., 2003), however, does not exclude an important contribution of GABAergic synaptic transmission in the induction of plasticity through the modulation of the activity pattern of the cortical circuits. It has been shown that the maturation of the inhibitory circuits during the development of the visual cortex is crucial for the opening of the CP of plasticity (Hensch, 1998; Iwai et al., 2003; Katagiri et al., 2007). Some experiments have also suggested that diffuse projection neuromodulatory systems of the brain stem, in particular those of acetylcholine, norepinephrine and serotonin, exert a facilitating role on cortical plasticity (Gu, 2002; Hong et al., 2020). A crucial issue emerging from numerous experiments is that MD plays on a mechanism of competition between the two eyes. The neurotrophic hypothesis claims that neurotrophins, synthesized and released from cortical neurons in an activity-dependent manner, are captured by the most active nerve terminals and transported retrogradely along the axons to the cell body where they exert their effect in terms of survival and strengthening of synaptic connections both at functional and morphological level (Berardi et al., 2003; Tropea et al., 2009). The transport of neurotrophic factors, however, occurs not only retrogradely, but also in anterograde direction (from the cell body to axons and dendrites) and a role for the anterograde action of BDNF in plasticity of the visual cortex has been suggested (Caleo et al., 2000). Other studies have shown that neurotrophins have an even more complex action in regulating plasticity processes with different effects on specific cell populations: it has been widely documented, for 
example, that BDNF is involved in the maturation of inhibitory neurons and that NGF promotes cholinergic transmission (Berardi et al., 2003; Tropea et al., 2009).

Once triggered by electrical activity, plasticity processes take place through the activation of a series of intracellular proteins, including the protein kinases PKA (protein kinase A), ERK (protein kinase regulated by extracellular signals) and CaMKII (protein calcium-calmodulin kinase dependent II), which can locally regulate the insertion of new receptors in the membrane of postsynaptic neurons or determine their removal, causing respectively a rapid increase or decrease in the synaptic response (Berardi et al., 2003; Tropea et al., 2009).

\section{Experience-dependent structural plasticity}

The activation of gene transcription and the synthesis of new proteins are necessary to make permanent changes in synaptic efficacy and to carry out the morphological changes underlying the phenomena of plasticity (Berardi et al., 2003; Tropea et al., 2009). Indeed, synaptic structural rearrangements are a crucial mechanism mediating neural circuit adaptation in the brain (Berry and Nedivi, 2016).

The classic studies by Hubel and Wiesel already reported that thalamocortical afferents carrying the visual information from each eye are not hardwired, with a shrinkage of thalamic terminals transmitting the stimuli from the closed eye and the expansion of the area of competence of the open eye after MD (Antonini and Stryker, 1993; Hubel et al., 1977; Shatz and Stryker, 1978). Few years later, it has been shown that thalamocortical remodeling is guided by changes in extragranular cortical stages, suggesting that alterations in the strength of long-range excitatory horizontal connections might be one of the upstream actors driving plasticity processes (Diamond et al., 1994; Trachtenberg et al., 2000). The more recent advent of techniques for in vivo direct visualization of structural dynamics of dendrites, axons, synaptic spines and glial processes allowed the chronic tracking of morphological changes on a smaller scale and experience-dependent structural plasticity was observed at subcellular level in developing sensory cortices, with a substantial alteration of spine motility and density in response to manipulations of sensory environment (Berry and Nedivi, 2016; Djurisic et al., 2013; Lendvai et al., 2000; Majewska and Sur, 2003; Mataga et al., 2004; Oray et al., 2004; Tropea et al., 2010). This anatomical reorganization is accompanied by the induction of the proteolytic activity of some enzymes aimed at degrading some components of the 
extracellular matrix, which, by exercising their function of supporting and anchoring the neurons, act as inhibitory factors for synaptic dynamism (Mataga et al., 2004; Oray et al., 2004).

A decline of dendritic and spine motility has been reported after the end of critical periods (Chen et al., 2012; Grutzendler et al., 2002; Holtmaat et al., 2005; Keck et al., 2008), but a refinement process of neuronal wiring continues in the adult brain where recent evidence demonstrates changes in circuit structure (Chen et al., 2012; Frenkel and Bear, 2004; Hofer et al., 2009; Holtmaat et al., 2005; Keck et al., 2011; Majewska et al., 2006; Montey and Quinlan, 2011), characterized by cell-type and laminar specificity (Chen et al., 2011; Lee et al., 2008, 2006). Presynaptic terminals are also dynamic on a cell-specific and experience-dependent scale in the adult neocortex (Chen et al., 2011; De Paola et al., 2006; Marik et al., 2010; Stettler et al., 2006).

Finally, functional and morphological changes of white matter and glial cells play a critical role in supporting experience-dependent synaptic modifications (Pietrasanta et al., 2014, 2012; Restani et al., 2009; Sipe et al., 2016).

A diagram summarizing the neural mechanisms underlying OD plasticity is reported in Figure 1A.

\section{Maladaptive plasticity: the paradigmatic case of amblyopia}

Alterations of environmental input during early temporal windows can determine the establishment of 'maladaptive' plasticity processes that lead to permanent changes in the organization of neural circuits and the onset of pathological conditions, potentially causing cortical blindness. By way of example, let's consider what happens in children suffering from bilateral congenital cataract: the lack of adequate visual stimulation, due to the opacification of the lens, hampers the maturation of different properties of the visual system and, if cataract is not promptly removed, it causes the irreversible impairment of vision (Maurer et al., 2005).

Equally disabling is the pathology arising from a unilateral alteration of visual experience (due to unequal alignment of the two eyes or lens defects affecting only one eye), known as amblyopia. Amblyopia is the most common cause of monocular decreased vision in children and young adults (Birch, 2013), and the clinical picture includes reduced visual acuity and contrast sensitivity in the amblyopic eye, accompanied by a disruption of cortical binocular connections leading to deficits in 
depth perception (Birch, 2013; Daw, 1998; Mitchell and MacKinnon, 2002; Simons, 2005). Current treatments for amblyopia rely on the long-term occlusion of the healthy, fellow eye of vision to force use of the amblyopic eye (Birch, 2013; Loudon and Simonsz, 2005). However, because of the age-dependent reduction of plasticity, an early beginning of the treatment is critical for obtaining optimal visual acuity outcome and children older than 7 years are significantly less responsive to the occlusion therapy (Birch, 2013).

\section{Neuroplasticity in the adult cortex}

The transition to adulthood entails a reduction in the plastic potential of the nervous circuits (Hooks and Chen, 2020, 2007; Ribic, 2020). However, growing experimental studies in animal models and humans have shown that rapid physiological plasticity can be enabled in the adult cortex as well (Binda et al., 2018; Lunghi et al., 2015a, 2015b, 2013, 2011; McCoy et al., 2009; Sawtell et al., 2003).

In the first place, a series of experiments in the mouse model instilled the idea that visual cortex plasticity is not restricted to the $\mathrm{CP}$ early in life and MD can stimulate the functional reorganization of adult visual circuits as well (Hofer et al., 2006; Sawtell et al., 2003, see figure 1C for a schematic representation of OD plasticity in adult animals), although the net effect of MD is quantitatively and qualitatively different in juveniles and adult mice (Frenkel and Bear, 2004; Hofer et al., 2006; Morishita and Hensch, 2008; Sato and Stryker, 2008). More specifically, young animals undergo a reduction in the cortical response driven by the deprived eye followed by a potentiation of the fellow eye response, whereas the adult visual cortex only exhibits the delayed potentiation of the open eye (Frenkel and Bear, 2004). Similar results have been reported in the primary somatosensory cortex, where whisker deprivation is still effective in reinforcing the responses to the stimulation of spared whiskers in layer II/III (Glazewski et al., 2000). Recent work in adult humans revealed that a very short period of MD (2-2.5 hours) induces a transient shift of OD surprisingly in favor of the deprived eye (Lunghi et al., 2013, 2011, figure 1D). The OD shift is observed both at the perceptual (Lunghi et al., 2013, 2011) and at the neural level (Binda et al., 2018; Binda and Lunghi, 2017; Lunghi et al., 2015a, 2015b), and it is thought to reflect a form homeostatic plasticity of the adult visual cortex aimed at maintaining the average activity constant in response to MD. At the perceptual level, the dominance shift is observed both for 
competitive (Lunghi et al., 2013, 2011) and collaborative interocular interactions and it may last for up to 3 hours after eye-patch removal depending on the visual stimulus used to test ocular dominance (Lunghi et al., 2013). Interestingly, the perceptual boost of the deprived eye responses following short-term MD has been also observed in amblyopic patients (Lunghi et al., 2019c, 2016; Zhou et al., 2019, 2014), indicating that homeostatic plasticity mechanisms operate in the amblyopic visual system and opening the way to new therapeutic approaches for the treatment of amblyopia (Lunghi et al., 2019c; Zhou et al., 2019). At the neural level, short-term $M D$ induces a transient change in OD in the primary visual cortex towards a direction consistent with the perceptual changes: the amplitude of the earliest component of the visual evoked potential (C1) increases for the deprived eye, while it decreases for the non-deprived eye (Lunghi et al., 2015a). A similar effect is also observed for steady-state responses measured by magnetoencephalography (Chadnova et al., 2017). Consistently, BOLD responses at the level of primary visual cortex are boosted for the deprived and depressed for the non-deprived eye, and this change is accompanied by a shift of neural tuning in favor of higher spatial frequencies (Binda et al., 2018). Moreover, the OD shift is also accompanied by a change in the intracortical excitation/inhibition balance: GABA concentration (measured by Magnetic Resonance Spectroscopy in the primary visual cortex), indeed, decreases of about $9 \%$ after 2.5 hours of MD (Lunghi et al., 2015b) and the amplitude of slow pupillary oscillations increases (Binda and Lunghi, 2017), indicating an involvement of cholinergic and noradrenergic systems as well.

\section{Rejuvenating the adult visual cortex}

Since OD plasticity is quantitatively larger in younger animals and residual plasticity in the adult brain appears to differ in many aspects from the plasticity measured during the CP (Medini, 2014; Sato and Stryker, 2008), several studies attempted to identify the molecular mechanisms responsible for this plasticity decline and to reinstate a window of opportunity for juvenile-like plasticity in adult animals (Castaldi et al., 2020; McCoy et al., 2009; Medini, 2014). Finding new strategies to enhance the plastic potential of the adult visual cortex is also instrumental to develop therapeutic approaches for the treatment of amblyopia and other neurodevelopmental disorders past the CP (L. Baroncelli et al., 2010; Hensch and Quinlan, 2018). 
The first factor that regulates the closure of CPs is experience itself. The lack of appropriate environmental stimulation, indeed, prolongs the temporal window of brain maturation. Once again the example of the visual system is paradigmatic: the visual cortex of animals reared in dark conditions from birth remains in a state of immaturity and MD is effective in modifying the OD properties of cortical neurons well after the closure of CP (Cynader and Mitchell, 1980; Fagiolini et al., 1994; Kang et al., 2013; Pizzorusso et al., 1997). Intriguingly, complete visual deprivation through dark exposure restores rapid OD plasticity and promotes amblyopia recovery in the adult visual cortex (He et al., 2007; Montey and Quinlan, 2011; Stodieck et al., 2014). In addition, temporary retinal inactivation efficiently drives recovery of visual function in amblyopic mice and kittens (Duffy et al., 2018; Fong et al., 2016) These results suggest that experience regulates the expression of cellular and molecular factors, whose maturation is responsible for restricting plasticity to CP (Berardi et al., 2003).

Neurotrophic factors were the first group of molecules for which a causal relationship between their action and the duration of the visual cortex $\mathrm{CP}$ has been established (Caleo and Maffei, 2002): dark rearing, indeed, reduces the expression of neurotrophic factors (Capsoni et al., 1999; Castrén et al., 1992; Viegi et al., 2002) and the blockage of their intracellular signalling pathways, induced by the administration of specific antibodies, significantly delays the closure of CP (Domenici et al., 1994; Zhang et al., 2018), while the overexpression of BDNF has the very opposite effect (Gianfranceschi et al., 2003; Hanover et al., 1999; Huang et al., 1999). Manipulation of BDNF signalling also affects experience-dependent plasticity in the auditory and barrel cortex (Anomal et al., 2013; Itami et al., 2007, 1998). These data made BDNF a very attractive candidate for the implementation of strategies aimed at drug delivery in amblyopic subjects and it has been recently reported that intranasal administration of this neurotrophin promotes the functional recovery of neural connections conveying sensory information from the amblyopic eye to the visual cortex (Sansevero et al., 2019). Importantly, the recovery effect induced by BDNF was evident not only in association with occlusion therapy, but also in binocular sight conditions, thus reinforcing the chance for clinical application to human patients (Hess and Thompson, 2015; Sansevero et al., 2019).

Dark rearing also delays the maturation of intracortical inhibitory circuits (Benevento et al., 1995; Morales et al., 2002) and induces a significant decrease of 
GABA receptors in the adult visual cortex (He et al., 2006) thus suggesting that the development of GABAergic neurotransmission represents one of the main driver in the regulation of experience-dependent plasticity. Accordingly, an early potentiation of inhibitory neurotransmission can induce a premature initiation and closure of visual cortex CP (Di Cristo et al., 2007; Fagiolini et al., 2004; Fagiolini and Hensch, 2000; Gao et al., 1999; Hanover et al., 1999; Hensch, 1998; Huang et al., 1999; Iwai et al., 2003; Krishnan et al., 2015; Sugiyama et al., 2008), and the pharmacological manipulation of the intracortical inhibitory tone completely restores plasticity in sensory cortices of adult animals (Beurdeley et al., 2012; Cisneros-Franco and de Villers-Sidani, 2019; Harauzov et al., 2010). In particular, fast-spiking parvalbumin (PV) and vasoactive intestinal peptide (VIP) interneurons powerfully affect the expression of cortical plasticity (Fu et al., 2015; Gu et al., 2016; Katagiri et al., 2007; Kuhlman et al., 2013; Niell and Stryker, 2010; Pi et al., 2013; Vickers et al., 2018). Recent results revealed an important function of $p 75$ neurotrophin receptor in the regulation of the time course of $\mathrm{PV}$ cell maturation and in limiting the remodelling of cortical circuits in adulthood (Baho et al., 2019).

In the attempt to identify translational strategies for pharmacological intervention, it has been shown that magnifying the neuromodulatory actions of acetylcholine and serotonin adjusts the excitatory/inhibitory balance of neural circuits enabling the recovery of plasticity in the adult visual cortex (Bachatene et al., 2013; Hong et al., 2020; Lagas et al., 2019; Maya Vetencourt et al., 2011, 2008; Morishita et al., 2010; Sajo et al., 2016; Sharif et al., 2019). The promising results of smallsample clinical trials endorse larger-scale trials of treatment with selective serotonin reuptake inhibitors for adult amblyopia (Lagas et al., 2019; Sharif et al., 2019).

By transferring our attention to the extracellular components of the nervous system, it has been documented that the maturation of the extracellular matrix determines the morphological stabilization of neural connections and that disrupting this physical network enables plasticity in the mature brain (Carulli et al., 2010; de Vivo et al., 2013; Fawcett et al., 2019; Murase et al., 2019, 2017; Pizzorusso, 2002; Pizzorusso et al., 2006). Extracellular matrix is particularly condensed in the socalled perineuronal nets (PNNs) enwrapping PV cells and the communication between PNNs and neuronal circuits is conveyed by semaphorin proteins (Boggio et al., 2019). Similar results have been achieved by molecular interference with 
myelination and myelin-related proteins (Bochner et al., 2014; McGee et al., 2005; Stephany et al., 2014; Syken, 2006).

Finally, epigenetic mechanisms such as DNA methylation and histone modifications downregulate the expression of plasticity-related genes over development and the manipulation of these repressive effects increases plasticity in adult cortex (Baroncelli et al., 2016; Putignano et al., 2007; Silingardi et al., 2010; Tognini et al., 2015). A coordinated action of some microRNAs and epigenetic factors is likely involved in the government of specific stages of brain maturation and plasticity (Mazziotti et al., 2017; Mellios et al., 2011; Napoli et al., 2020; Remenyi et al., 2013; Tognini et al., 2011).

An exciting development in the field is that environmental and behavioral protocols can be used to enhance adult visual cortex plasticity and these noninvasive strategies might be more easily translated to clinical therapies (Bonaccorsi et al., 2014; Sale et al., 2014). One of the most promising approaches for the potential application to the clinics is environmental enrichment promoting robust OD plasticity and a complete recovery from amblyopia in adult rodents through a reduction of intracortical inhibition (Laura Baroncelli et al., 2010; Greifzu et al., 2014; Sale et al., 2007; Scali et al., 2012). The crucial components promoting visual plasticity observed in enriched animals is voluntary physical activity (Baroncelli et al., 2012). Physical exercise can enhance the gain of visual cortical activity (Niell and Stryker, 2010) and neural plasticity in adult rodents (Baroncelli et al., 2012) by reducing the inhibitory tone: cholinergic projections from the basal forebrain triggered by locomotion selectively activate a disinhibitory interneuron circuit (containing both VIP and somatostatin GABAergic interneurons) in the primary visual cortex, with the net effect of releasing pyramidal neurons from inhibition (Fu et al., 2015, 2014). In addition to the decrease of the intracortical inhibitory tone, the beneficial effects of physical activity on brain plasticity might be mediated by an alteration of energy metabolism. Growing evidence suggests an interplay between energy metabolism and plasticity: obesity is associated with deficits in cognitive functions and increased liability to neurodegenerative diseases (Guillemot-Legris and Muccioli, 2017), and caloric restriction promotes neuronal plasticity in adult rodents (Spolidoro et al., 2011). Consistently, a recent work reported that visual homeostatic plasticity in response to short-term MD is impaired in morbidly obese adult humans (Lunghi et al., 2019a). 
Taken together, these results suggest that physical exercise might be a powerful candidate as a non-invasive therapeutic strategy to promote visual plasticity also in humans. This hypothesis has been supported by recent studies showing that moderate physical exercise can enhance visual homeostatic plasticity in adult humans (Lunghi et al., 2019c; Lunghi and Sale, 2016, 2015). Importantly, the combination of physical exercise and short-term deprivation of the amblyopic eye effectively promoted the long-term recovery of both visual acuity and stereopsis in adult amblyopic subjects (Lunghi et al., 2019c). It is also compelling to note that the adult visual cortex retains learning competences and this is reflected into the success of perceptual learning protocols to promote recovery from amblyopia in rodents (Baroncelli et al., 2012; Bonaccorsi et al., 2014). Some perceptual improvement has been demonstrated in human patients as well, with the essential ingredients of visual training protocols being incorporated into video game formats for home-based interventions (Astle et al., 2011; Green and Bavelier, 2012; Levi and Li, 2009; Tsirlin et al., 2015). These data indicate that a combined approach including both physical activity and visual training could maximize the recovery of visual system function. A schematic representation of the strategies endorsing the reopening of a critical period in adulthood and the underlying neural mechanisms is reported in Figure 1B.

\section{Neuroplasticity in the time of retinal disorders}

Retinal degenerative disorders, including retinitis pigmentosa (RP) and macular degeneration $(\mathrm{MaD})$, are among the principal causes of adult-onset blindness worldwide (Parmeggiani, 2011; Wong et al., 2014). There is no effective cure for these disorders, but research aimed at preventing photoreceptor loss, or at substituting light-responsive elements, is catalyzing new hope for patients (Aguirre et al., 2007; Cohen, 2007; Dias et al., 2018; Lagali et al., 2008; Maya-Vetencourt et al., 2020, 2017; Strettoi et al., 2010; Thyagarajan et al., 2010). In particular, retinal prostheses electrically stimulating the residual retinal neurons represent an emerging technology in the treatment of such diseases and have been shown to restore some useful vision, substantially improving the quality of life of patients (Castaldi et al., 2020, 2016; Mills et al., 2017), but a number of other therapeutic approaches recently moved to the clinical phase and novel biological products are coming to the market (Dias et al., 2018; Mandai et al., 2017a, 2017b; Russell et al., 2017). 
All potential therapeutic strategies for retinal disorders, however, rely on the integrity of the visual system downstream of photoreceptors to deliver effective and meaningful visual information to the central stations. Moreover, potentially maladaptive changes of cortical circuits could take place in neurodegenerative conditions (Dumoulin and Knapen, 2018; Merabet and Pascual-Leone, 2010) and characterizing plastic reorganization induced by visual defects is essential for any attempt to develop efficient strategies for disease management and rehabilitation.

Morphological investigation suggested a relatively good preservation of the visual pathway conveying sensory information from photoreceptors to the cortex, despite a progressive remodelling of inner retinal neurons and glial cells (Aguirre et al., 2007; Marc et al., 2003; Mazzoni et al., 2008; Milam et al., 1998; Ohno et al., 2015; Schoth et al., 2006; Strettoi et al., 2003). At the functional level, however, retinal ganglion cells (RGCs) displayed a deterioration of the signal to noise ratio, due to a combination of decreased light-evoked responses and a significant increase of spontaneous activity (Margolis et al., 2008; Menzler and Zeck, 2011; Sekirnjak et al., 2011; Stasheff, 2008). Reduced light responsiveness and poor signal to noise ratio are also described in the lateral geniculate nucleus and superior colliculus (Alexander et al., 2005; Sauvé et al., 2001), and electrical stimulation of the optic nerve requires higher threshold to elicit the perception of phosphenes in RP patients (Gothe et al., 2002).

In the framework of retinal disorders, the visual cortex has received surprisingly little attention, although this brain region is the stage where important information processing occurs. Recently, a voxel-based morphometry study showed a significant reduction in gray matter volume of the occipital cortex in RP patients with the pattern of degeneration correlated to the extent of visual field loss (Machado et al., 2017; Sanda et al., 2018). Magnetic resonance imaging highlighted the sparing of some visual responses in the striate and extrastriate cortex of patients affected with RP (Castaldi et al., 2019; Masuda et al., 2010), but electrophysiological properties of visual cortical neurons, including orientation selectivity, spatial and temporal frequency tuning and receptive field size appeared very degraded in animal models (Chen et al., 2016; Gias et al., 2011).

Despite these general alterations of neuronal activity, we recently reported that RP cortical circuits retain a remarkable capability of input-dependent remodelling: more specifically, physiological ocular dominance and synaptic plasticity 
are observed in the primary visual cortex of a murine model of RP (rd10 mouse) (Begenisic et al., 2020, figure 1E) and RP patients show a degree of visual homeostatic plasticity induced by short-term MD comparable to healthy control subjects (Lunghi et al., 2019b, figure 1F). Since successful application of eyetargeted intervention treatments requires that the visual cortex is able to adapt to the restored visual input, the preservation of sufficient levels of plasticity is highly relevant in therapeutic perspective. More detailed functional mapping revealed an alteration of intrinsic activity and synchronicity in the visual cortex, with higher threshold for eliciting cortical responses, loss of retinotopy, visual network disconnection and reorganization of the retino-cortical pathway, in particular at the level of dorsal stream. These changes seem to be dependent on the magnitude of visual deficits and can be explained by cortical adaptation mechanisms (Dan et al., 2019; Ferreira et al., 2017, 2014; Huang et al., 2018; Lunghi et al., 2019b; Nimmagadda and Weiland, 2018). Moreover, the visual cortex receives inputs from other sensory modalities that can be rapidly unmasked and take over cortical processing in conditions of retinal degeneration (Cunningham et al., 2011; Merabet et al., 2008; Merabet and Pascual-Leone, 2010; Röder et al., 2002; Sabbah et al., 2017; Sadato et al., 1996). Altogether, these data suggest that the design of therapeutic strategies, and in particular of retinal prosthesis, should include a level of flexibility that accounts for the patient-specific variability of cortical activity.

In contrast to RP, commonly causing a full degradation of the visual field, MaD patients present with a focused degeneration of the macula and their peripheral vision is not damaged (Mitchell et al., 2018), despite a volumetric reduction of structures along the visual pathway (Hernowo et al., 2014) and a significant cortical atrophy across the whole occipital lobe (Beer et al., 2020; Hanson et al., 2019). It is worth noting that large-scale compensatory reorganization of cortical circuits could be set in motion by retinal degeneration in multiple areas of $\mathrm{MaD}$ visual cortex (Baker et al., 2005; Baseler et al., 2011; Cheung and Legge, 2005; Dilks et al., 2014; Shao et al., 2013). In this pathology, the implant of exogenous prostheses leads the retina to respond to electrical stimulation in its central part and to natural light pattern in the peripheral healthy portion. The visual cortex seems to homogeneously adjust these concurrent stimuli presumably thanks to intact cortico-cortical connections (Haak et al., 2016), encouraging the use of prosthetic devices for the restoration of 
sight in AMD patients (Arens-Arad et al., 2020; Haak et al., 2016; Lorach et al., 2015).

An additional leading cause of irreversible blindness worldwide is glaucoma, a neurodegenerative disorder characterized by the progressive degeneration of the optic nerve and visual field loss (Kasi et al., 2019). Currently, the standard of care for glaucoma patients envisages multiple treatments aimed at lowering intraocular pressure and reducing the risk of vision impairment. However, the disorder can continue to advance even at reduced intraocular pressure and novel therapeutic options targeting other key factors of disease onset and progression might reduce the prevalence of glaucoma (Kasi et al., 2019). Despite the lack of spontaneous recovery of the damaged optic nerve, recent evidence suggests that proper stimulation of RGCs, alone or in combination with the modulation of intrinsic cell growth-promoting factors, induces full-length axonal regeneration in the visual pathway up to the correct target regions in lateral geniculate nucleus, superior colliculus, and other visual centers. This morphological recovery and the reestablishment of accurate circuit connections are accompanied by the reinstatement of simple visual-dependent behaviors, such as optomotor response, depth perception, and circadian photoentrainment (Bei et al., 2016; de Lima et al., 2012; Kurimoto et al., 2010; Lim et al., 2016; Li et al., 2015; Murphy et al., 2016; Wang et al., 2018).

\section{Conclusions}

The capability of the visual cortex to remodel in response to environmental pressures is essential for the rehabilitation of visual diseases, especially in adulthood, when the plastic potential of the cerebral cortex is thought to be reduced. Altogether, the studies reviewed here force us to rethink the importance experience-dependent plasticity in adulthood and in the case of visual diseases.

During the past decade, growing evidence demonstrates that the adult visual cortex retains a degree of neural plasticity higher than previously thought, which can be further enhanced by non-invasive environmental manipulations, such as voluntary physical activity. These findings pave the way for the development of non-invasive therapeutic strategies for visual diseases that were thought to be untreatable in adults (e.g. amblyopia), with potential broader applications for neuro-rehabilitation in adults (e.g. rehabilitation after stroke) and the prevention of pathological brain aging. 
Furthermore, recent evidence shows that the plastic potential of the visual cortex is preserved in clinical populations with retinal disorders, despite a degraded visual input. This advance in our understanding of visual cortical plasticity is encouraging for the development of new therapies aimed at reactivating the visual cortex of blind individuals (e.g. by artificially restoring retinal input by means of retinal implants), indicating that in these patients the deafferented visual cortex might have the potential to rewire and benefit from these prospective treatments.

Acknowledgements: This work was supported by a grant from Fondazione Roma, Call for Proposals 2013 (grant agreement 109/AI) to LB and by the French National Research Agency (ANR), AAPG 2019 JCJC (grant agreement ANR-19-CE28-0008, PlaStiC) to CL.

Conflict of Interest: The authors declare no competing financial interests.

\section{Reference list}

Aguirre, G.K., Komáromy, A.M., Cideciyan, A.V., Brainard, D.H., Aleman, T.S., Roman, A.J., Avants, B.B., Gee, J.C., Korczykowski, M., Hauswirth, W.W., Acland, G.M., Aguirre, G.D., Jacobson, S.G., 2007. Canine and human visual cortex intact and responsive despite early retinal blindness from RPE65 mutation. PLoS Med. 4, e230.

Alexander, K.R., Rajagopalan, A.S., Seiple, W., Zemon, V.M., Fishman, G.A., 2005. Contrast response properties of magnocellular and parvocellular pathways in retinitis pigmentosa assessed by the visual evoked potential. Invest. Ophthalmol. Vis. Sci. 46, 2967-2973.

Anomal, R., de Villers-Sidani, E., Merzenich, M.M., Panizzutti, R., 2013. Manipulation of BDNF signaling modifies the experience-dependent plasticity induced by pure tone exposure during the critical period in the primary auditory cortex. PLoS One 8, e64208.

Antonini, A., Stryker, M.P., 1993. Rapid remodeling of axonal arbors in the visual cortex. Science 260, 1819-1821.

Arens-Arad, T., Farah, N., Lender, R., Moshkovitz, A., Flores, T., Palanker, D., Mandel, Y., 2020. Cortical Interactions between Prosthetic and Natural Vision. Curr. Biol. 30, 176-182.e2.

Astle, A.T., Webb, B.S., McGraw, P.V., 2011. Can perceptual learning be used to treat amblyopia beyond the critical period of visual development? Ophthalmic Physiol. Opt. 31, 564-573.

Bachatene, L., Bharmauria, V., Cattan, S., Molotchnikoff, S., 2013. Fluoxetine and serotonin facilitate attractive-adaptation-induced orientation plasticity in adult cat visual cortex. Eur. J. Neurosci. 38, 2065-2077. 
Baho, E., Chattopadhyaya, B., Lavertu-Jolin, M., Mazziotti, R., Awad, P.N., Chehrazi, P., Groleau, M., Jahannault-Talignani, C., Vaucher, E., Ango, F., Pizzorusso, T., Baroncelli, L., Di Cristo, G., 2019. p75 Neurotrophin Receptor Activation Regulates the Timing of the Maturation of Cortical Parvalbumin Interneuron Connectivity and Promotes Juvenile-like Plasticity in Adult Visual Cortex. J. Neurosci. 39, 4489-4510.

Baker, C.I., Peli, E., Knouf, N., Kanwisher, N.G., 2005. Reorganization of visual processing in macular degeneration. J. Neurosci. 25, 614-618.

Baroncelli, L., Bonaccorsi, J., Milanese, M., Bonifacino, T., Giribaldi, F., Manno, I., Cenni, M.C., Berardi, N., Bonanno, G., Maffei, L., Sale, A., 2012. Enriched experience and recovery from amblyopia in adult rats: impact of motor, social and sensory components. Neuropharmacology 62, 2388-2397.

Baroncelli, L., Braschi, C., Spolidoro, M., Begenisic, T., Sale, A., Maffei, L., 2010. Nurturing brain plasticity: impact of environmental enrichment. Cell Death Differ. 17, 1092-1103.

Baroncelli, L., Sale, A., Viegi, A., Maya Vetencourt, J.F., De Pasquale, R., Baldini, S., Maffei, L., 2010. Experience-dependent reactivation of ocular dominance plasticity in the adult visual cortex. Exp. Neurol. 226, 100-109.

Baroncelli, L., Scali, M., Sansevero, G., Olimpico, F., Manno, I., Costa, M., Sale, A., 2016. Experience Affects Critical Period Plasticity in the Visual Cortex through an Epigenetic Regulation of Histone Post-Translational Modifications. J. Neurosci. 36, 3430-3440.

Baseler, H.A., Gouws, A., Haak, K.V., Racey, C., Crossland, M.D., Tufail, A., Rubin, G.S., Cornelissen, F.W., Morland, A.B., 2011. Large-scale remapping of visual cortex is absent in adult humans with macular degeneration. Nat. Neurosci. 14, 649-655.

Bear, M.F., 2003. Bidirectional synaptic plasticity: from theory to reality. Philos.

Trans. R. Soc. Lond. B Biol. Sci. 358, 649-655.

Beer, A.L., Plank, T., Greenlee, M.W., 2020. Aging and central vision loss:

Relationship between the cortical macro-structure and micro-structure.

Neuroimage 212, 116670.

Begenisic, T., Mazziotti, R., Sagona, G., Lupori, L., Sale, A., Galli, L., Baroncelli, L., 2020. Preservation of Visual Cortex Plasticity in Retinitis Pigmentosa. Neuroscience. https://doi.org/10.1016/j.neuroscience.2019.10.045

Bei, F., Lee, H.H.C., Liu, X., Gunner, G., Jin, H., Ma, L., Wang, C., Hou, L., Hensch, T.K., Frank, E., Sanes, J.R., Chen, C., Fagiolini, M., He, Z., 2016. Restoration of Visual Function by Enhancing Conduction in Regenerated Axons. Cell 164, 219-232.

Benevento, L.A., Bakkum, B.W., Cohen, R.S., 1995. gamma-Aminobutyric acid and somatostatin immunoreactivity in the visual cortex of normal and dark-reared rats. Brain Res. 689, 172-182.

Berardi, N., Pizzorusso, T., Maffei, L., 2000. Critical periods during sensory development. Curr. Opin. Neurobiol. 10, 138-145.

Berardi, N., Pizzorusso, T., Ratto, G.M., Maffei, L., 2003. Molecular basis of plasticity in the visual cortex. Trends Neurosci. 26, 369-378.

Berardi, N., Sale, A., Maffei, L., 2015. Brain structural and functional development: genetics and experience. Dev. Med. Child Neurol. 57 Suppl 2, 4-9.

Berry, K.P., Nedivi, E., 2016. Experience-Dependent Structural Plasticity in the Visual System. Annu Rev Vis Sci 2, 17-35.

Beurdeley, M., Spatazza, J., Lee, H.H.C., Sugiyama, S., Bernard, C., Di Nardo, A.A., 
Hensch, T.K., Prochiantz, A., 2012. Otx2 binding to perineuronal nets persistently regulates plasticity in the mature visual cortex. J. Neurosci. 32, 9429-9437.

Binda, P., Kurzawski, J.W., Lunghi, C., Biagi, L., Tosetti, M., Morrone, M.C., 2018. Response to short-term deprivation of the human adult visual cortex measured with 7T BOLD. Elife 7. https://doi.org/10.7554/eLife.40014

Binda, P., Lunghi, C., 2017. Short-Term Monocular Deprivation Enhances Physiological Pupillary Oscillations. Neural Plast. 2017, 6724631.

Birch, E.E., 2013. Amblyopia and binocular vision. Prog. Retin. Eye Res. 33, 67-84. Bochner, D.N., Sapp, R.W., Adelson, J.D., Zhang, S., Lee, H., Djurisic, M., Syken, J., Dan, Y., Shatz, C.J., 2014. Blocking PirB up-regulates spines and functional synapses to unlock visual cortical plasticity and facilitate recovery from amblyopia. Sci. Transl. Med. 6, 258ra140.

Boggio, E.M., Ehlert, E.M., Lupori, L., Moloney, E.B., De Winter, F., Vander Kooi, C.W., Baroncelli, L., Mecollari, V., Blits, B., Fawcett, J.W., Verhaagen, J., Pizzorusso, T., 2019. Inhibition of Semaphorin3A Promotes Ocular Dominance Plasticity in the Adult Rat Visual Cortex. Mol. Neurobiol. 56, 5987-5997.

Bonaccorsi, J., Berardi, N., Sale, A., 2014. Treatment of amblyopia in the adult: insights from a new rodent model of visual perceptual learning. Front. Neural Circuits 8, 82.

Caleo, M., Maffei, L., 2002. Neurotrophins and plasticity in the visual cortex. Neuroscientist 8, 52-61.

Caleo, M., Menna, E., Chierzi, S., Cenni, M.C., Maffei, L., 2000. Brain-derived neurotrophic factor is an anterograde survival factor in the rat visual system. Curr. Biol. 10, 1155-1161.

Capsoni, S., Tongiorgi, E., Cattaneo, A., Domenici, L., 1999. Differential regulation of brain-derived neurotrophic factor messenger RNA cellular expression in the adult rat visual cortex. Neuroscience 93, 1033-1040.

Carulli, D., Pizzorusso, T., Kwok, J.C.F., Putignano, E., Poli, A., Forostyak, S., Andrews, M.R., Deepa, S.S., Glant, T.T., Fawcett, J.W., 2010. Animals lacking link protein have attenuated perineuronal nets and persistent plasticity. Brain 133, 2331-2347.

Castaldi, E., Cicchini, G.M., Cinelli, L., Biagi, L., Rizzo, S., Morrone, M.C., 2016. Visual BOLD Response in Late Blind Subjects with Argus II Retinal Prosthesis. PLoS Biol. 14, e1002569.

Castaldi, E., Cicchini, G.M., Falsini, B., Binda, P., Morrone, M.C., 2019. Residual Visual Responses in Patients With Retinitis Pigmentosa Revealed by Functional Magnetic Resonance Imaging. Transl. Vis. Sci. Technol. 8, 44.

Castaldi, E., Lunghi, C., Morrone, M.C., 2020. Neuroplasticity in adult human visual cortex. Neurosci. Biobehav. Rev. 112, 542-552.

Castrén, E., Zafra, F., Thoenen, H., Lindholm, D., 1992. Light regulates expression of brain-derived neurotrophic factor mRNA in rat visual cortex. Proc. Natl. Acad. Sci. U. S. A. 89, 9444-9448.

Chadnova, E., Reynaud, A., Clavagnier, S., Hess, R.F., 2017. Short-term monocular occlusion produces changes in ocular dominance by a reciprocal modulation of interocular inhibition. Sci. Rep. 7, 41747.

Chen, J.L., Lin, W.C., Cha, J.W., So, P.T., Kubota, Y., Nedivi, E., 2011. Structural basis for the role of inhibition in facilitating adult brain plasticity. Nat. Neurosci. 14, 587-594.

Chen, J.L., Villa, K.L., Cha, J.W., So, P.T.C., Kubota, Y., Nedivi, E., 2012. Clustered 
dynamics of inhibitory synapses and dendritic spines in the adult neocortex. Neuron 74, 361-373.

Chen, K., Wang, Y., Liang, X., Zhang, Y., Ng, T.K., Chan, L.L.H., 2016. Electrophysiology Alterations in Primary Visual Cortex Neurons of Retinal Degeneration (S334ter-line-3) Rats. Sci. Rep. 6, 26793.

Cheung, S.-H., Legge, G.E., 2005. Functional and cortical adaptations to central vision loss. Vis. Neurosci. 22, 187-201.

Cisneros-Franco, J.M., de Villers-Sidani, É., 2019. Reactivation of critical period plasticity in adult auditory cortex through chemogenetic silencing of parvalbumin-positive interneurons. Proc. Natl. Acad. Sci. U. S. A. https://doi.org/10.1073/pnas.1913227117

Cohen, E.D., 2007. Prosthetic interfaces with the visual system: biological issues. J. Neural Eng. 4, R14-31.

Cooke, S.F., Bear, M.F., 2010. Visual experience induces long-term potentiation in the primary visual cortex. J. Neurosci. 30, 16304-16313.

Crozier, R.A., Wang, Y., Liu, C.-H., Bear, M.F., 2007. Deprivation-induced synaptic depression by distinct mechanisms in different layers of mouse visual cortex. Proc. Natl. Acad. Sci. U. S. A. 104, 1383-1388.

Cunningham, S.I., Weiland, J.D., Bao, P., Tjan, B.S., 2011. Visual cortex activation induced by tactile stimulation in late-blind individuals with retinitis pigmentosa. Conf. Proc. IEEE Eng. Med. Biol. Soc. 2011, 2841-2844.

Cynader, M., Mitchell, D.E., 1980. Prolonged sensitivity to monocular deprivation in dark-reared cats. J. Neurophysiol. 43, 1026-1040.

Dan, H.-D., Zhou, F.-Q., Huang, X., Xing, Y.-Q., Shen, Y., 2019. Altered intra- and inter-regional functional connectivity of the visual cortex in individuals with peripheral vision loss due to retinitis pigmentosa. Vision Res. 159, 68-75.

Daw, N., Rao, Y., Wang, X.-F., Fischer, Q., Yang, Y., 2004. LTP and LTD vary with layer in rodent visual cortex. Vision Res. 44, 3377-3380.

Daw, N.W., 1998. Critical periods and amblyopia. Arch. Ophthalmol. 116, 502-505. de Lima, S., Koriyama, Y., Kurimoto, T., Oliveira, J.T., Yin, Y., Li, Y., Gilbert, H.-Y., Fagiolini, M., Martinez, A.M.B., Benowitz, L., 2012. Full-length axon regeneration in the adult mouse optic nerve and partial recovery of simple visual behaviors. Proc. Natl. Acad. Sci. U. S. A. 109, 9149-9154.

De Paola, V., Holtmaat, A., Knott, G., Song, S., Wilbrecht, L., Caroni, P., Svoboda, K., 2006. Cell type-specific structural plasticity of axonal branches and boutons in the adult neocortex. Neuron 49, 861-875.

de Vivo, L., Landi, S., Panniello, M., Baroncelli, L., Chierzi, S., Mariotti, L., Spolidoro, M., Pizzorusso, T., Maffei, L., Ratto, G.M., 2013. Extracellular matrix inhibits structural and functional plasticity of dendritic spines in the adult visual cortex. Nat. Commun. 4, 1484.

Diamond, M.E., Huang, W., Ebner, F.F., 1994. Laminar comparison of somatosensory cortical plasticity. Science 265, 1885-1888.

Dias, M.F., Joo, K., Kemp, J.A., Fialho, S.L., da Silva Cunha, A., Jr, Woo, S.J., Kwon, Y.J., 2018. Molecular genetics and emerging therapies for retinitis pigmentosa: Basic research and clinical perspectives. Prog. Retin. Eye Res. 63, 107-131.

Di Cristo, G., Chattopadhyaya, B., Kuhlman, S.J., Fu, Y., Bélanger, M.-C., Wu, C.Z., Rutishauser, U., Maffei, L., Huang, Z.J., 2007. Activity-dependent PSA expression regulates inhibitory maturation and onset of critical period plasticity. Nat. Neurosci. 10, 1569-1577. 
Dilks, D.D., Julian, J.B., Peli, E., Kanwisher, N., 2014. Reorganization of visual processing in age-related macular degeneration depends on foveal loss. Optom. Vis. Sci. 91, e199-206.

Djurisic, M., Vidal, G.S., Mann, M., Aharon, A., Kim, T., Ferrao Santos, A., Zuo, Y., Hübener, M., Shatz, C.J., 2013. PirB regulates a structural substrate for cortical plasticity. Proc. Natl. Acad. Sci. U. S. A. 110, 20771-20776.

Dölen, G., Bear, M.F., 2008. Role for metabotropic glutamate receptor 5 (mGluR5) in the pathogenesis of fragile $X$ syndrome. J. Physiol. 586, 1503-1508.

Domenici, L., Cellerino, A., Berardi, N., Cattaneo, A., Maffei, L., 1994. Antibodies to nerve growth factor (NGF) prolong the sensitive period for monocular deprivation in the rat. Neuroreport 5, 2041-2044.

Duffy, K.R., Fong, M.-F., Mitchell, D.E., Bear, M.F., 2018. Recovery from the anatomical effects of long-term monocular deprivation in cat lateral geniculate nucleus. J. Comp. Neurol. 526, 310-323.

Dumoulin, S.O., Knapen, T., 2018. How Visual Cortical Organization Is Altered by Ophthalmologic and Neurologic Disorders. Annu Rev Vis Sci 4, 357-379.

Fagiolini, M., Fritschy, J.-M., Löw, K., Möhler, H., Rudolph, U., Hensch, T.K., 2004. Specific GABAA circuits for visual cortical plasticity. Science 303, 1681-1683.

Fagiolini, M., Hensch, T.K., 2000. Inhibitory threshold for critical-period activation in primary visual cortex. Nature 404, 183-186.

Fagiolini, M., Pizzorusso, T., Berardi, N., Domenici, L., Maffei, L., 1994. Functional postnatal development of the rat primary visual cortex and the role of visual experience: dark rearing and monocular deprivation. Vision Res. 34, 709-720.

Fawcett, J.W., Oohashi, T., Pizzorusso, T., 2019. The roles of perineuronal nets and the perinodal extracellular matrix in neuronal function. Nat. Rev. Neurosci. 20, 451-465.

Ferreira, S., Pereira, A.C., Quendera, B., Mateus, C., Silva, E., Castelo-Branco, M., 2014. Brain structural and functional reorganization due to long term retinal peripheral degeneration in retinitis pigmentosa. Acta Ophthalmologica. https://doi.org/10.1111/j.1755-3768.2014.3676.x

Ferreira, S., Pereira, A.C., Quendera, B., Reis, A., Silva, E.D., Castelo-Branco, M., 2017. Primary visual cortical remapping in patients with inherited peripheral retinal degeneration. Neuroimage Clin 13, 428-438.

Fong, M.-F., Mitchell, D.E., Duffy, K.R., Bear, M.F., 2016. Rapid recovery from the effects of early monocular deprivation is enabled by temporary inactivation of the retinas. Proc. Natl. Acad. Sci. U. S. A. 113, 14139-14144.

Frenkel, M.Y., Bear, M.F., 2004. How monocular deprivation shifts ocular dominance in visual cortex of young mice. Neuron 44, 917-923.

Fu, Y., Kaneko, M., Tang, Y., Alvarez-Buylla, A., Stryker, M.P., 2015. A cortical disinhibitory circuit for enhancing adult plasticity. Elife 4, e05558.

Fu, Y., Tucciarone, J.M., Espinosa, J.S., Sheng, N., Darcy, D.P., Nicoll, R.A., Huang, Z.J., Stryker, M.P., 2014. A cortical circuit for gain control by behavioral state. Cell 156, 1139-1152.

Gao, W.J., Newman, D.E., Wormington, A.B., Pallas, S.L., 1999. Development of inhibitory circuitry in visual and auditory cortex of postnatal ferrets:

immunocytochemical localization of GABAergic neurons. J. Comp. Neurol. 409, 261-273.

Gianfranceschi, L., Siciliano, R., Walls, J., Morales, B., Kirkwood, A., Huang, Z.J., Tonegawa, S., Maffei, L., 2003. Visual cortex is rescued from the effects of dark rearing by overexpression of BDNF. Proc. Natl. Acad. Sci. U. S. A. 100, 12486- 
12491.

Gias, C., Vugler, A., Lawrence, J., Carr, A.J., Chen, L.L., Ahmado, A., Semo, M. 'ayan, Coffey, P.J., 2011. Degeneration of cortical function in the Royal College of Surgeons rat. Vision Res. 51, 2176-2185.

Glazewski, S., Giese, K.P., Silva, A., Fox, K., 2000. The role of alpha-CaMKII autophosphorylation in neocortical experience-dependent plasticity. Nat. Neurosci. 3, 911-918.

Gothe, J., Brandt, S.A., Irlbacher, K., Röricht, S., Sabel, B.A., Meyer, B.-U., 2002. Changes in visual cortex excitability in blind subjects as demonstrated by transcranial magnetic stimulation. Brain 125, 479-490.

Green, C.S., Bavelier, D., 2012. Learning, attentional control, and action video games. Curr. Biol. 22, R197-206.

Greifzu, F., Pielecka-Fortuna, J., Kalogeraki, E., Krempler, K., Favaro, P.D., Schlüter, O.M., Löwel, S., 2014. Environmental enrichment extends ocular dominance plasticity into adulthood and protects from stroke-induced impairments of plasticity. Proc. Natl. Acad. Sci. U. S. A. 111, 1150-1155.

Grutzendler, J., Kasthuri, N., Gan, W.-B., 2002. Long-term dendritic spine stability in the adult cortex. Nature 420, 812-816.

Guillemot-Legris, O., Muccioli, G.G., 2017. Obesity-Induced Neuroinflammation: Beyond the Hypothalamus. Trends Neurosci. 40, 237-253.

$\mathrm{Gu}, \mathrm{Q}$., 2002. Neuromodulatory transmitter systems in the cortex and their role in cortical plasticity. Neuroscience 111, 815-835.

Gu, Y., Tran, T., Murase, S., Borrell, A., Kirkwood, A., Quinlan, E.M., 2016. Neuregulin-Dependent Regulation of Fast-Spiking Interneuron Excitability Controls the Timing of the Critical Period. J. Neurosci. 36, 10285-10295.

Haak, K.V., Morland, A.B., Rubin, G.S., Cornelissen, F.W., 2016. Preserved retinotopic brain connectivity in macular degeneration. Ophthalmic Physiol. Opt. 36, 335-343.

Hanover, J.L., Huang, Z.J., Tonegawa, S., Stryker, M.P., 1999. Brain-derived neurotrophic factor overexpression induces precocious critical period in mouse visual cortex. J. Neurosci. 19, RC40.

Hanson, R.L.W., Gale, R.P., Gouws, A.D., Airody, A., Scott, M.T.W., Akthar, F., Waterson, S., Wells, M.T., Wright, A.J., Bell, K., Silson, E., Baseler, H.A., Morland, A.B., 2019. Following the Status of Visual Cortex Over Time in Patients With Macular Degeneration Reveals Atrophy of Visually Deprived Brain Regions. Invest. Ophthalmol. Vis. Sci. 60, 5045-5051.

Harauzov, A., Spolidoro, M., DiCristo, G., De Pasquale, R., Cancedda, L., Pizzorusso, T., Viegi, A., Berardi, N., Maffei, L., 2010. Reducing intracortical inhibition in the adult visual cortex promotes ocular dominance plasticity. J. Neurosci. 30, 361-371.

Hebb, D.O., 1949. Review of Neurology. Canadian Journal of Psychology Revue Canadienne de Psychologie. https://doi.org/10.1037/h0084100

He, H.-Y., Hodos, W., Quinlan, E.M., 2006. Visual deprivation reactivates rapid ocular dominance plasticity in adult visual cortex. J. Neurosci. 26, 2951-2955.

He, H.-Y., Ray, B., Dennis, K., Quinlan, E.M., 2007. Experience-dependent recovery of vision following chronic deprivation amblyopia. Nat. Neurosci. 10, 1134-1136.

Hensch, T.K., 2004. Critical period regulation. Annu. Rev. Neurosci. 27, 549-579.

Hensch, T.K., 1998. Local GABA Circuit Control of Experience-Dependent Plasticity in Developing Visual Cortex. Science.

https://doi.org/10.1126/science.282.5393.1504 
Hensch, T.K., Quinlan, E.M., 2018. Critical periods in amblyopia. Vis. Neurosci. 35, E014.

Hernowo, A.T., Prins, D., Baseler, H.A., Plank, T., Gouws, A.D., Hooymans, J.M.M., Morland, A.B., Greenlee, M.W., Cornelissen, F.W., 2014. Morphometric analyses of the visual pathways in macular degeneration. Cortex 56, 99-110.

Hess, R.F., Thompson, B., 2015. Amblyopia and the binocular approach to its therapy. Vision Res. 114, 4-16.

Heynen, A.J., Yoon, B.-J., Liu, C.-H., Chung, H.J., Huganir, R.L., Bear, M.F., 2003. Molecular mechanism for loss of visual cortical responsiveness following brief monocular deprivation. Nat. Neurosci. 6, 854-862.

Hofer, S.B., Mrsic-Flogel, T.D., Bonhoeffer, T., Hübener, M., 2009. Experience leaves a lasting structural trace in cortical circuits. Nature 457, 313-317.

Hofer, S.B., Mrsic-Flogel, T.D., Bonhoeffer, T., Hubener, M., 2006. Prior experience enhances plasticity in adult visual cortex. American Journal of Ophthalmology. https://doi.org/10.1016/j.ajo.2006.04.002

Holtmaat, A.J.G.D., Trachtenberg, J.T., Wilbrecht, L., Shepherd, G.M., Zhang, X., Knott, G.W., Svoboda, K., 2005. Transient and persistent dendritic spines in the neocortex in vivo. Neuron 45, 279-291.

Hong, S.Z., Huang, S., Severin, D., Kirkwood, A., 2020. Pull-push neuromodulation of cortical plasticity enables rapid bi-directional shifts in ocular dominance. Elife 9. https://doi.org/10.7554/eLife.54455

Hooks, B.M., Chen, C., 2020. Circuitry Underlying Experience-Dependent Plasticity in the Mouse Visual System. Neuron 107, 986-987.

Hooks, B.M., Chen, C., 2007. Critical Periods in the Visual System: Changing Views for a Model of Experience-Dependent Plasticity. Neuron.

https://doi.org/10.1016/j.neuron.2007.10.003

Horton, J.C., Hocking, D.R., 1997. Timing of the critical period for plasticity of ocular dominance columns in macaque striate cortex. J. Neurosci. 17, 3684-3709.

Huang, X., Zhou, F.-Q., Dan, H.-D., Shen, Y., 2018. Abnormal intrinsic brain activity in individuals with peripheral vision loss because of retinitis pigmentosa using amplitude of low-frequency fluctuations. Neuroreport 29, 1323-1332.

Huang, Z.J., Kirkwood, A., Pizzorusso, T., Porciatti, V., Morales, B., Bear, M.F., Maffei, L., Tonegawa, S., 1999. BDNF regulates the maturation of inhibition and the critical period of plasticity in mouse visual cortex. Cell 98, 739-755.

Hubel, D.H., Wiesel, T.N., LeVay, S., 1977. Plasticity of ocular dominance columns in monkey striate cortex. Philos. Trans. R. Soc. Lond. B Biol. Sci. 278, 377-409.

Issa, N.P., Trachtenberg, J.T., Chapman, B., Zahs, K.R., Stryker, M.P., 1999. The critical period for ocular dominance plasticity in the Ferret's visual cortex. J. Neurosci. 19, 6965-6978.

Itami, C., Kimura, F., Nakamura, S., 2007. Brain-derived neurotrophic factor regulates the maturation of layer 4 fast-spiking cells after the second postnatal week in the developing barrel cortex. J. Neurosci. 27, 2241-2252.

Itami, C., Mizuno, K., Kohno, T., Nakamura, S., 1998. Role of BDNF in neuronal plasticity in barrel field. Neuroscience Research. https://doi.org/10.1016/s01680102(98)82470-X

Iwai, Y., Fagiolini, M., Obata, K., Hensch, T.K., 2003. Rapid critical period induction by tonic inhibition in visual cortex. J. Neurosci. 23, 6695-6702.

Kaneko, M., Stryker, M.P., 2017. Homeostatic plasticity mechanisms in mouse V1. Philos. Trans. R. Soc. Lond. B Biol. Sci. 372. https://doi.org/10.1098/rstb.2016.0504 
Kang, E., Durand, S., LeBlanc, J.J., Hensch, T.K., Chen, C., Fagiolini, M., 2013. Visual acuity development and plasticity in the absence of sensory experience. J. Neurosci. 33, 17789-17796.

Kasi, A., Faiq, M.A., Chan, K.C., 2019. imaging of structural, metabolic and functional brain changes in glaucoma. Neural Regeneration Res. 14, 446-449.

Katagiri, H., Fagiolini, M., Hensch, T.K., 2007. Optimization of somatic inhibition at critical period onset in mouse visual cortex. Neuron 53, 805-812.

Keck, T., Mrsic-Flogel, T.D., Vaz Afonso, M., Eysel, U.T., Bonhoeffer, T., Hübener, M., 2008. Massive restructuring of neuronal circuits during functional reorganization of adult visual cortex. Nat. Neurosci. 11, 1162-1167.

Keck, T., Scheuss, V., Jacobsen, R.I., Wierenga, C.J., Eysel, U.T., Bonhoeffer, T., Hübener, M., 2011. Loss of sensory input causes rapid structural changes of inhibitory neurons in adult mouse visual cortex. Neuron 71, 869-882.

Kirkwood, A., Bear, M.F., 1994. Hebbian synapses in visual cortex. J. Neurosci. 14, 1634-1645.

Krishnan, K., Wang, B.-S., Lu, J., Wang, L., Maffei, A., Cang, J., Huang, Z.J., 2015. MeCP2 regulates the timing of critical period plasticity that shapes functional connectivity in primary visual cortex. Proc. Natl. Acad. Sci. U. S. A. 112, E478291.

Kuhlman, S.J., Olivas, N.D., Tring, E., Ikrar, T., Xu, X., Trachtenberg, J.T., 2013. A disinhibitory microcircuit initiates critical-period plasticity in the visual cortex. Nature 501, 543-546.

Kurimoto, T., Yin, Y., Omura, K., Gilbert, H.-Y., Kim, D., Cen, L.-P., Moko, L., Kügler, S., Benowitz, L.I., 2010. Long-distance axon regeneration in the mature optic nerve: contributions of oncomodulin, cAMP, and pten gene deletion. J. Neurosci. 30, 15654-15663.

Lagali, P.S., Balya, D., Awatramani, G.B., Münch, T.A., Kim, D.S., Busskamp, V., Cepko, C.L., Roska, B., 2008. Light-activated channels targeted to ON bipolar cells restore visual function in retinal degeneration. Nat. Neurosci. 11, 667-675.

Lagas, A.K., Black, J.M., Russell, B.R., Kydd, R.R., Thompson, B., 2019. The Effect of Combined Patching and Citalopram on Visual Acuity in Adults with Amblyopia: A Randomized, Crossover, Placebo-Controlled Trial. Neural Plast. 2019, 5857243.

Lee, W.-C.A., Chen, J.L., Huang, H., Leslie, J.H., Amitai, Y., So, P.T., Nedivi, E., 2008. A dynamic zone defines interneuron remodeling in the adult neocortex. Proceedings of the National Academy of Sciences. https://doi.org/10.1073/pnas.0810149105

Lee, W.-C.A., Huang, H., Feng, G., Sanes, J.R., Brown, E.N., So, P.T., Nedivi, E., 2006. Dynamic remodeling of dendritic arbors in GABAergic interneurons of adult visual cortex. PLoS Biol. 4, e29.

Lehmann, K., Löwel, S., 2008. Age-dependent ocular dominance plasticity in adult mice. PLoS One 3, e3120.

Lendvai, B., Stern, E.A., Chen, B., Svoboda, K., 2000. Experience-dependent plasticity of dendritic spines in the developing rat barrel cortex in vivo. Nature 404, 876-881.

Levi, D.M., Li, R.W., 2009. Perceptual learning as a potential treatment for amblyopia: A mini-review. Vision Research. https://doi.org/10.1016/j.visres.2009.02.010

Lim, J.-H.A., Stafford, B.K., Nguyen, P.L., Lien, B.V., Wang, C., Zukor, K., He, Z., Huberman, A.D., 2016. Neural activity promotes long-distance, target-specific 
regeneration of adult retinal axons. Nat. Neurosci. 19, 1073-1084.

Li, S., He, Q., Wang, H., Tang, X., Ho, K.W., Gao, X., Zhang, Q., Shen, Y., Cheung, A., Wong, F., Wong, Y.H., Ip, N.Y., Jiang, L., Yung, W.H., Liu, K., 2015. Injured adult retinal axons with Pten and Socs3 co-deletion reform active synapses with suprachiasmatic neurons. Neurobiology of Disease.

https://doi.org/10.1016/j.nbd.2014.09.019

Lorach, H., Lei, X., Galambos, L., Kamins, T., Mathieson, K., Dalal, R., Huie, P., Harris, J., Palanker, D., 2015. Interactions of Prosthetic and Natural Vision in Animals With Local Retinal Degeneration. Invest. Ophthalmol. Vis. Sci. 56, 7444-7450.

Loudon, S.E., Simonsz, H.J., 2005. The history of the treatment of amblyopia. Strabismus 13, 93-106.

Lunghi, C., Berchicci, M., Morrone, M.C., Di Russo, F., 2015a. Short-term monocular deprivation alters early components of visual evoked potentials. J. Physiol. 593, 4361-4372.

Lunghi, C., Burr, D.C., Morrone, C., 2011. Brief periods of monocular deprivation disrupt ocular balance in human adult visual cortex. Curr. Biol. 21, R538-9.

Lunghi, C., Burr, D.C., Morrone, M.C., 2013. Long-term effects of monocular deprivation revealed with binocular rivalry gratings modulated in luminance and in color. J. Vis. 13. https://doi.org/10.1167/13.6.1

Lunghi, C., Daniele, G., Binda, P., Dardano, A., Ceccarini, G., Santini, F., Del Prato, S., Morrone, M.C., 2019a. Altered Visual Plasticity in Morbidly Obese Subjects. iScience 22, 206-213.

Lunghi, C., Emir, U.E., Morrone, M.C., Bridge, H., 2015b. Short-term monocular deprivation alters GABA in the adult human visual cortex. Curr. Biol. 25, 14961501.

Lunghi, C., Galli-Resta, L., Binda, P., Cicchini, G.M., Placidi, G., Falsini, B., Morrone, M.C., 2019b. Visual Cortical Plasticity in Retinitis Pigmentosa. Investigative Opthalmology \& Visual Science. https://doi.org/10.1167/iovs.18-25750

Lunghi, C., Morrone, M.C., Secci, J., Caputo, R., 2016. Binocular Rivalry Measured 2 Hours After Occlusion Therapy Predicts the Recovery Rate of the Amblyopic Eye in Anisometropic Children. Invest. Ophthalmol. Vis. Sci. 57, 1537-1546.

Lunghi, C., Sale, A., 2016. Moderate levels of physical activity enhance short-term visual plasticity in adult humans. Journal of Vision.

https://doi.org/10.1167/16.12.1100

Lunghi, C., Sale, A., 2015. A cycling lane for brain rewiring. Curr. Biol. 25, R1122-3.

Lunghi, C., Sframeli, A.T., Lepri, A., Lepri, M., Lisi, D., Sale, A., Morrone, M.C., 2019c. A new counterintuitive training for adult amblyopia. Ann Clin Transl Neurol 6, 274-284.

Machado, A.R., Pereira, A.C., Ferreira, F., Ferreira, S., Quendera, B., Silva, E., Castelo-Branco, M., 2017. Structure-function correlations in Retinitis Pigmentosa patients with partially preserved vision: a voxel-based morphometry study. Scientific Reports. https://doi.org/10.1038/s41598-017-11317-7

Majewska, A.K., Newton, J.R., Sur, M., 2006. Remodeling of synaptic structure in sensory cortical areas in vivo. J. Neurosci. 26, 3021-3029.

Majewska, A., Sur, M., 2003. Motility of dendritic spines in visual cortex in vivo: changes during the critical period and effects of visual deprivation. Proc. Natl. Acad. Sci. U. S. A. 100, 16024-16029.

Mandai, M., Fujii, M., Hashiguchi, T., Sunagawa, G.A., Ito, S.-I., Sun, J., Kaneko, J., Sho, J., Yamada, C., Takahashi, M., 2017a. iPSC-Derived Retina Transplants 
Improve Vision in rd1 End-Stage Retinal-Degeneration Mice. Stem Cell Reports 8, 1112-1113.

Mandai, M., Kurimoto, Y., Takahashi, M., 2017b. Autologous Induced Stem-CellDerived Retinal Cells for Macular Degeneration. N. Engl. J. Med.

Marc, R.E., Jones, B.W., Watt, C.B., Strettoi, E., 2003. Neural remodeling in retinal degeneration. Progress in Retinal and Eye Research.

https://doi.org/10.1016/s1350-9462(03)00039-9

Margolis, D.J., Newkirk, G., Euler, T., Detwiler, P.B., 2008. Functional stability of retinal ganglion cells after degeneration-induced changes in synaptic input. J. Neurosci. 28, 6526-6536.

Marik, S.A., Yamahachi, H., McManus, J.N.J., Szabo, G., Gilbert, C.D., 2010. Axonal dynamics of excitatory and inhibitory neurons in somatosensory cortex. PLoS Biol. 8, e1000395.

Masuda, Y., Horiguchi, H., Dumoulin, S.O., Furuta, A., Miyauchi, S., Nakadomari, S., Wandell, B.A., 2010. Task-dependent $\mathrm{V} 1$ responses in human retinitis pigmentosa. Invest. Ophthalmol. Vis. Sci. 51, 5356-5364.

Mataga, N., Mizuguchi, Y., Hensch, T.K., 2004. Experience-dependent pruning of dendritic spines in visual cortex by tissue plasminogen activator. Neuron 44, 1031-1041.

Maurer, D., Lewis, T.L., Mondloch, C.J., 2005. Missing sights: consequences for visual cognitive development. Trends Cogn. Sci. 9, 144-151.

Maya-Vetencourt, J.F., Ghezzi, D., Antognazza, M.R., Colombo, E., Mete, M., Feyen, P., Desii, A., Buschiazzo, A., Di Paolo, M., Di Marco, S., Ticconi, F., Emionite, L., Shmal, D., Marini, C., Donelli, I., Freddi, G., Maccarone, R., Bisti, S., Sambuceti, G., Pertile, G., Lanzani, G., Benfenati, F., 2017. A fully organic retinal prosthesis restores vision in a rat model of degenerative blindness. Nat. Mater. 16, 681-689.

Maya-Vetencourt, J.F., Manfredi, G., Mete, M., Colombo, E., Bramini, M., Di Marco, S., Shmal, D., Mantero, G., Dipalo, M., Rocchi, A., DiFrancesco, M.L., Papaleo, E.D., Russo, A., Barsotti, J., Eleftheriou, C., Di Maria, F., Cossu, V., Piazza, F., Emionite, L., Ticconi, F., Marini, C., Sambuceti, G., Pertile, G., Lanzani, G., Benfenati, F., 2020. Subretinally injected semiconducting polymer nanoparticles rescue vision in a rat model of retinal dystrophy. Nat. Nanotechnol. https://doi.org/10.1038/s41565-020-0696-3

Maya Vetencourt, J.F., Sale, A., Viegi, A., Baroncelli, L., De Pasquale, R., O'Leary, O.F., Castrén, E., Maffei, L., 2008. The antidepressant fluoxetine restores plasticity in the adult visual cortex. Science 320, 385-388.

Maya Vetencourt, J.F., Tiraboschi, E., Spolidoro, M., Castrén, E., Maffei, L., 2011. Serotonin triggers a transient epigenetic mechanism that reinstates adult visual cortex plasticity in rats. Eur. J. Neurosci. 33, 49-57.

Mazziotti, R., Baroncelli, L., Ceglia, N., Chelini, G., Sala, G.D., Magnan, C., Napoli, D., Putignano, E., Silingardi, D., Tola, J., Tognini, P., Arthur, J.S.C., Baldi, P., Pizzorusso, T., 2017. Mir-132/212 is required for maturation of binocular matching of orientation preference and depth perception. Nat. Commun. 8, 15488.

Mazzoni, F., Novelli, E., Strettoi, E., 2008. Retinal ganglion cells survive and maintain normal dendritic morphology in a mouse model of inherited photoreceptor degeneration. J. Neurosci. 28, 14282-14292.

McCoy, P.A., Huang, H.-S., Philpot, B.D., 2009. Advances in understanding visual cortex plasticity. Curr. Opin. Neurobiol. 19, 298-304. 
McGee, A.W., Yang, Y., Fischer, Q.S., Daw, N.W., Strittmatter, S.M., 2005. Experience-driven plasticity of visual cortex limited by myelin and Nogo receptor. Science 309, 2222-2226.

Medini, P., 2014. Experience-dependent plasticity of visual cortical microcircuits. Neuroscience 278, 367-384.

Mellios, N., Sugihara, H., Castro, J., Banerjee, A., Le, C., Kumar, A., Crawford, B., Strathmann, J., Tropea, D., Levine, S.S., Edbauer, D., Sur, M., 2011. miR-132, an experience-dependent microRNA, is essential for visual cortex plasticity. Nat. Neurosci. 14, 1240-1242.

Menzler, J., Zeck, G., 2011. Network oscillations in rod-degenerated mouse retinas. J. Neurosci. 31, 2280-2291.

Merabet, L.B., Hamilton, R., Schlaug, G., Swisher, J.D., Kiriakopoulos, E.T., Pitskel, N.B., Kauffman, T., Pascual-Leone, A., 2008. Rapid and reversible recruitment of early visual cortex for touch. PLoS One 3, e3046.

Merabet, L.B., Pascual-Leone, A., 2010. Neural reorganization following sensory loss: the opportunity of change. Nat. Rev. Neurosci. 11, 44-52.

Milam, A.H., Li, Z.Y., Fariss, R.N., 1998. Histopathology of the human retina in retinitis pigmentosa. Prog. Retin. Eye Res. 17, 175-205.

Mills, J.O., Jalil, A., Stanga, P.E., 2017. Electronic retinal implants and artificial vision: journey and present. Eye 31, 1383-1398.

Mitchell, D.E., MacKinnon, S., 2002. The present and potential impact of research on animal models for clinical treatment of stimulus deprivation amblyopia. Clinical and Experimental Optometry. https://doi.org/10.1111/j.14440938.2002.tb03067.x

Mitchell, P., Liew, G., Gopinath, B., Wong, T.Y., 2018. Age-related macular degeneration. Lancet 392, 1147-1159.

Montey, K.L., Quinlan, E.M., 2011. Recovery from chronic monocular deprivation following reactivation of thalamocortical plasticity by dark exposure. Nat. Commun. 2, 317.

Morales, B., Choi, S.-Y., Kirkwood, A., 2002. Dark rearing alters the development of GABAergic transmission in visual cortex. J. Neurosci. 22, 8084-8090.

Morishita, H., Hensch, T.K., 2008. Critical period revisited: impact on vision. Curr. Opin. Neurobiol. 18, 101-107.

Morishita, H., Miwa, J.M., Heintz, N., Hensch, T.K., 2010. Lynx1, a cholinergic brake, limits plasticity in adult visual cortex. Science 330, 1238-1240.

Murase, S., Lantz, C.L., Quinlan, E.M., 2017. Light reintroduction after dark exposure reactivates plasticity in adults via perisynaptic activation of MMP-9. Elife 6. https://doi.org/10.7554/eLife.27345

Murase, S., Winkowski, D., Liu, J., Kanold, P.O., Quinlan, E.M., 2019. Homeostatic regulation of perisynaptic matrix metalloproteinase 9 (MMP9) activity in the amblyopic visual cortex. Elife 8. https://doi.org/10.7554/eLife.52503

Murphy, M.C., Conner, I.P., Teng, C.Y., Lawrence, J.D., Safiullah, Z., Wang, B., Bilonick, R.A., Kim, S.-G., Wollstein, G., Schuman, J.S., Chan, K.C., 2016. Retinal Structures and Visual Cortex Activity are Impaired Prior to Clinical Vision Loss in Glaucoma. Sci. Rep. 6, 31464.

Napoli, D., Lupori, L., Mazziotti, R., Sagona, G., Bagnoli, S., Samad, M., Sacramento, E.K., Kirkpartick, J., Putignano, E., Chen, S., Terzibasi Tozzini, E., Tognini, P., Baldi, P., Kwok, J.C., Cellerino, A., Pizzorusso, T., 2020. MiR-29 coordinates age-dependent plasticity brakes in the adult visual cortex. EMBO Rep. e50431. 
Niell, C.M., Stryker, M.P., 2010. Modulation of visual responses by behavioral state in mouse visual cortex. Neuron 65, 472-479.

Nimmagadda, K., Weiland, J.D., 2018. Retinotopic Responses in the Visual Cortex Elicited by Epiretinal Electrical Stimulation in Normal and Retinal Degenerate Rats. Transl. Vis. Sci. Technol. 7, 33.

Ohno, N., Murai, H., Suzuki, Y., Kiyosawa, M., Tokumaru, A.M., Ishii, K., OhnoMatsui, K., 2015. Alteration of the optic radiations using diffusion-tensor MRI in patients with retinitis pigmentosa. Br. J. Ophthalmol. 99, 1051-1054.

Oray, S., Majewska, A., Sur, M., 2004. Dendritic spine dynamics are regulated by monocular deprivation and extracellular matrix degradation. Neuron 44, $1021-$ 1030.

Parmeggiani, F., 2011. Clinics, epidemiology and genetics of retinitis pigmentosa. Curr. Genomics 12, 236-237.

Pietrasanta, M., Restani, L., Caleo, M., 2012. The corpus callosum and the visual cortex: plasticity is a game for two. Neural Plast. 2012, 838672.

Pietrasanta, M., Restani, L., Cerri, C., Olcese, U., Medini, P., Caleo, M., 2014. A switch from inter-ocular to inter-hemispheric suppression following monocular deprivation in the rat visual cortex. Eur. J. Neurosci. 40, 2283-2292.

Pi, H.-J., Hangya, B., Kvitsiani, D., Sanders, J.I., Huang, Z.J., Kepecs, A., 2013. Cortical interneurons that specialize in disinhibitory control. Nature 503, $521-$ 524.

Pizzorusso, T., 2002. Reactivation of Ocular Dominance Plasticity in the Adult Visual Cortex. Science. https://doi.org/10.1126/science.1072699

Pizzorusso, T., Fagiolini, M., Porciatti, V., Maffei, L., 1997. Temporal aspects of contrast visual evoked potentials in the pigmented rat: effect of dark rearing. Vision Res. 37, 389-395.

Pizzorusso, T., Medini, P., Landi, S., Baldini, S., Berardi, N., Maffei, L., 2006.

Structural and functional recovery from early monocular deprivation in adult rats. Proc. Natl. Acad. Sci. U. S. A. 103, 8517-8522.

Putignano, E., Lonetti, G., Cancedda, L., Ratto, G., Costa, M., Maffei, L., Pizzorusso, T., 2007. Developmental downregulation of histone posttranslational modifications regulates visual cortical plasticity. Neuron 53, 747-759.

Remenyi, J., van den Bosch, M.W.M., Palygin, O., Mistry, R.B., McKenzie, C., Macdonald, A., Hutvagner, G., Arthur, J.S.C., Frenguelli, B.G., Pankratov, Y., 2013. miR-132/212 knockout mice reveal roles for these miRNAs in regulating cortical synaptic transmission and plasticity. PLoS One 8, e62509.

Restani, L., Cerri, C., Pietrasanta, M., Gianfranceschi, L., Maffei, L., Caleo, M., 2009. Functional masking of deprived eye responses by callosal input during ocular dominance plasticity. Neuron 64, 707-718.

Ribic, A., 2020. Stability in the Face of Change: Lifelong Experience-Dependent Plasticity in the Sensory Cortex. Front. Cell. Neurosci. 14, 76.

Röder, B., Stock, O., Bien, S., Neville, H., Rösler, F., 2002. Speech processing activates visual cortex in congenitally blind humans. Eur. J. Neurosci. 16, 930936.

Russell, S., Bennett, J., Wellman, J.A., Chung, D.C., Yu, Z.-F., Tillman, A., Wittes, J., Pappas, J., Elci, O., McCague, S., Cross, D., Marshall, K.A., Walshire, J., Kehoe, T.L., Reichert, H., Davis, M., Raffini, L., George, L.A., Hudson, F.P., Dingfield, L., Zhu, X., Haller, J.A., Sohn, E.H., Mahajan, V.B., Pfeifer, W., Weckmann, M., Johnson, C., Gewaily, D., Drack, A., Stone, E., Wachtel, K., Simonelli, F., Leroy, B.P., Wright, J.F., High, K.A., Maguire, A.M., 2017. Efficacy 
and safety of voretigene neparvovec (AAV2-hRPE65v2) in patients with RPE65mediated inherited retinal dystrophy: a randomised, controlled, open-label, phase 3 trial. Lancet 390, 849-860.

Sabbah, N., Sanda, N., Authié, C.N., Mohand-Saïd, S., Sahel, J.-A., Habas, C., Amedi, A., Safran, A.B., 2017. Reorganization of early visual cortex functional connectivity following selective peripheral and central visual loss. Sci. Rep. 7, 43223.

Sadato, N., Pascual-Leone, A., Grafman, J., Ibañez, V., Deiber, M.P., Dold, G., Hallett, M., 1996. Activation of the primary visual cortex by Braille reading in blind subjects. Nature 380, 526-528.

Sajo, M., Ellis-Davies, G., Morishita, H., 2016. Lynx1 Limits Dendritic Spine Turnover in the Adult Visual Cortex. J. Neurosci. 36, 9472-9478.

Sale, A., Berardi, N., Maffei, L., 2014. Environment and brain plasticity: towards an endogenous pharmacotherapy. Physiol. Rev. 94, 189-234.

Sale, A., Maya Vetencourt, J.F., Medini, P., Cenni, M.C., Baroncelli, L., De Pasquale, R., Maffei, L., 2007. Environmental enrichment in adulthood promotes amblyopia recovery through a reduction of intracortical inhibition. Nat. Neurosci. $10,679-681$.

Sanda, N., Cerliani, L., Authié, C.N., Sabbah, N., Sahel, J.-A., Habas, C., Safran, A.B., Thiebaut de Schotten, M., 2018. Visual brain plasticity induced by central and peripheral visual field loss. Brain Struct. Funct. 223, 3473-3485.

Sansevero, G., Baroncelli, L., Scali, M., Sale, A., 2019. Intranasal BDNF administration promotes visual function recovery in adult amblyopic rats. Neuropharmacology 145, 114-122.

Sato, M., Stryker, M.P., 2008. Distinctive features of adult ocular dominance plasticity. J. Neurosci. 28, 10278-10286.

Sauvé, Y., Girman, S.V., Wang, S., Lawrence, J.M., Lund, R.D., 2001. Progressive visual sensitivity loss in the Royal College of Surgeons rat: perimetric study in the superior colliculus. Neuroscience 103, 51-63.

Sawtell, N.B., Frenkel, M.Y., Philpot, B.D., Nakazawa, K., Tonegawa, S., Bear, M.F., 2003. NMDA receptor-dependent ocular dominance plasticity in adult visual cortex. Neuron 38, 977-985.

Scali, M., Baroncelli, L., Cenni, M.C., Sale, A., Maffei, L., 2012. A rich environmental experience reactivates visual cortex plasticity in aged rats. Exp. Gerontol. 47, 337-341.

Schoth, F., Burgel, U., Dorsch, R., Reinges, M.H.T., Krings, T., 2006. Diffusion tensor imaging in acquired blind humans. Neurosci. Lett. 398, 178-182.

Sekirnjak, C., Jepson, L.H., Hottowy, P., Sher, A., Dabrowski, W., Litke, A.M., Chichilnisky, E.J., 2011. Changes in physiological properties of rat ganglion cells during retinal degeneration. J. Neurophysiol. 105, 2560-2571.

Shao, Y., Keliris, G.A., Papanikolaou, A., Fischer, M.D., Zobor, D., Jägle, H., Logothetis, N.K., Smirnakis, S.M., 2013. Visual cortex organisation in a macaque monkey with macular degeneration. Eur. J. Neurosci. 38, 3456-3464.

Sharif, M.H., Talebnejad, M.R., Rastegar, K., Khalili, M.R., Nowroozzadeh, M.H., 2019. Oral fluoxetine in the management of amblyopic patients aged between 10 and 40 years old: a randomized clinical trial. Eye 33, 1060-1067.

Shatz, C.J., Stryker, M.P., 1978. Ocular dominance in layer IV of the cat's visual cortex and the effects of monocular deprivation. J. Physiol. 281, 267-283.

Silingardi, D., Scali, M., Belluomini, G., Pizzorusso, T., 2010. Epigenetic treatments of adult rats promote recovery from visual acuity deficits induced by long-term 
monocular deprivation. Eur. J. Neurosci. 31, 2185-2192.

Simons, K., 2005. Amblyopia characterization, treatment, and prophylaxis. Surv. Ophthalmol. 50, 123-166.

Sipe, G.O., Lowery, R.L., Tremblay, M.-È., Kelly, E.A., Lamantia, C.E., Majewska, A.K., 2016. Microglial P2Y12 is necessary for synaptic plasticity in mouse visual cortex. Nat. Commun. 7, 10905.

Spolidoro, M., Baroncelli, L., Putignano, E., Maya-Vetencourt, J.F., Viegi, A., Maffei, L., 2011. Food restriction enhances visual cortex plasticity in adulthood. Nat. Commun. 2, 320.

Stasheff, S.F., 2008. Emergence of sustained spontaneous hyperactivity and temporary preservation of OFF responses in ganglion cells of the retinal degeneration (rd1) mouse. J. Neurophysiol. 99, 1408-1421.

Stephany, C.-É., Chan, L.L.H., Parivash, S.N., Dorton, H.M., Piechowicz, M., Qiu, S., McGee, A.W., 2014. Plasticity of binocularity and visual acuity are differentially limited by nogo receptor. J. Neurosci. 34, 11631-11640.

Stettler, D.D., Yamahachi, H., Li, W., Denk, W., Gilbert, C.D., 2006. Axons and synaptic boutons are highly dynamic in adult visual cortex. Neuron 49, 877-887.

Stodieck, S.K., Greifzu, F., Goetze, B., Schmidt, K.-F., Löwel, S., 2014. Brief dark exposure restored ocular dominance plasticity in aging mice and after a cortical stroke. Exp. Gerontol. 60, 1-11.

Strettoi, E., Gargini, C., Novelli, E., Sala, G., Piano, I., Gasco, P., Ghidoni, R., 2010. Inhibition of ceramide biosynthesis preserves photoreceptor structure and function in a mouse model of retinitis pigmentosa. Proc. Natl. Acad. Sci. U. S. A. 107, 18706-18711.

Strettoi, E., Pignatelli, V., Rossi, C., Porciatti, V., Falsini, B., 2003. Remodeling of second-order neurons in the retina of $\mathrm{rd} / \mathrm{rd}$ mutant mice. Vision Res. 43, 867877.

Sugiyama, S., Di Nardo, A.A., Aizawa, S., Matsuo, I., Volovitch, M., Prochiantz, A., Hensch, T.K., 2008. Experience-dependent transfer of Otx2 homeoprotein into the visual cortex activates postnatal plasticity. Cell 134, 508-520.

Syken, J., 2006. PirB Restricts Ocular-Dominance Plasticity in Visual Cortex. Science. https://doi.org/10.1126/science.1128232

Takesian, A.E., Hensch, T.K., 2013. Balancing plasticity/stability across brain development. Prog. Brain Res. 207, 3-34.

Thyagarajan, S., van Wyk, M., Lehmann, K., Löwel, S., Feng, G., Wässle, H., 2010. Visual function in mice with photoreceptor degeneration and transgenic expression of channelrhodopsin 2 in ganglion cells. J. Neurosci. 30, 8745-8758.

Tognini, P., Napoli, D., Tola, J., Silingardi, D., Della Ragione, F., D’Esposito, M., Pizzorusso, T., 2015. Experience-dependent DNA methylation regulates plasticity in the developing visual cortex. Nat. Neurosci. 18, 956-958.

Tognini, P., Putignano, E., Coatti, A., Pizzorusso, T., 2011. Experience-dependent expression of miR-132 regulates ocular dominance plasticity. Nat. Neurosci. 14, 1237-1239.

Trachtenberg, J.T., Trepel, C., Stryker, M.P., 2000. Rapid extragranular plasticity in the absence of thalamocortical plasticity in the developing primary visual cortex. Science 287, 2029-2032.

Tropea, D., Majewska, A.K., Garcia, R., Sur, M., 2010. Structural dynamics of synapses in vivo correlate with functional changes during experience-dependent plasticity in visual cortex. J. Neurosci. 30, 11086-11095.

Tropea, D., Van Wart, A., Sur, M., 2009. Molecular mechanisms of experience- 
dependent plasticity in visual cortex. Philos. Trans. R. Soc. Lond. B Biol. Sci. 364, 341-355.

Tsirlin, I., Colpa, L., Goltz, H.C., Wong, A.M.F., 2015. Behavioral Training as New Treatment for Adult Amblyopia: A Meta-Analysis and Systematic Review. Invest. Ophthalmol. Vis. Sci. 56, 4061-4075.

Turrigiano, G.G., 2017. The dialectic of Hebb and homeostasis. Philos. Trans. R. Soc. Lond. B Biol. Sci. 372. https://doi.org/10.1098/rstb.2016.0258

Vickers, E.D., Clark, C., Osypenko, D., Fratzl, A., Kochubey, O., Bettler, B., Schneggenburger, R., 2018. Parvalbumin-Interneuron Output Synapses Show Spike-Timing-Dependent Plasticity that Contributes to Auditory Map Remodeling. Neuron 99, 720-735.e6.

Viegi, A., Cotrufo, T., Berardi, N., Mascia, L., Maffei, L., 2002. Effects of dark rearing on phosphorylation of neurotrophin Trk receptors. Eur. J. Neurosci. 16, 19251930.

Wang, R., Tang, Z., Sun, X., Wu, L., Wang, J., Zhong, Y., Xiao, Z., 2018. White Matter Abnormalities and Correlation With Severity in Normal Tension Glaucoma: A Whole Brain Atlas-Based Diffusion Tensor Study. Invest. Ophthalmol. Vis. Sci. 59, 1313-1322.

Wiesel, T.N., Hubel, D.H., 1965. Comparison of the effects of unilateral and bilateral eye closure on cortical unit responses in kittens. J. Neurophysiol. 28, 10291040.

Wiesel, T.N., Hubel, D.H., 1963. SINGLE-CELL RESPONSES IN STRIATE CORTEX OF KITTENS DEPRIVED OF VISION IN ONE EYE. J. Neurophysiol. 26, 1003-1017.

Wong, W.L., Su, X., Li, X., Cheung, C.M.G., Klein, R., Cheng, C.-Y., Wong, T.Y., 2014. Global prevalence of age-related macular degeneration and disease burden projection for 2020 and 2040: a systematic review and meta-analysis. The Lancet Global Health. https://doi.org/10.1016/s2214-109x(13)70145-1

Zhang, H., Mu, L., Wang, D., Xia, D., Salmon, A., Liu, Q., Wong-Riley, M.T.T., 2018. Uncovering a critical period of synaptic imbalance during postnatal development of the rat visual cortex: role of brain-derived neurotrophic factor. J. Physiol. 596, 4511-4536.

Zhou, J., He, Z., Wu, Y., Chen, Y., Chen, X., Liang, Y., Mao, Y., Yao, Z., Lu, F., Qu, J., Hess, R.F., 2019. Inverse Occlusion: A Binocularly Motivated Treatment for Amblyopia. Neural Plast. 2019, 5157628.

Zhou, J., McNeal, S., Babu, R.J., Baker, D.H., Bobier, W.R., Hess, R.F., 2014. Time course of dichoptic masking in normals and suppression in amblyopes. Invest. Ophthalmol. Vis. Sci. 55, 4098-4104.

\section{Figure}




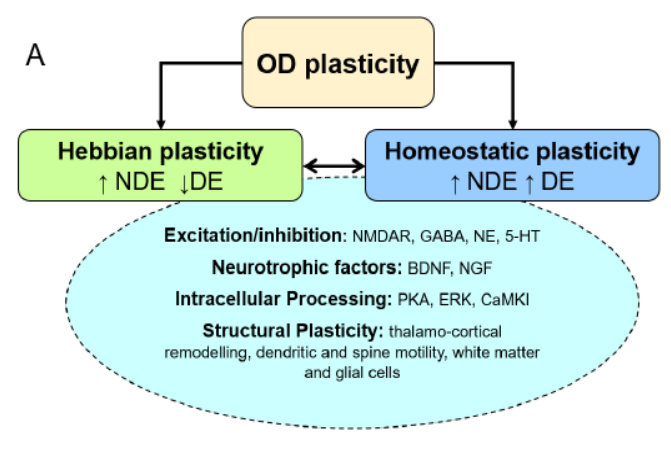

OD plasticity in adults and retinal disease
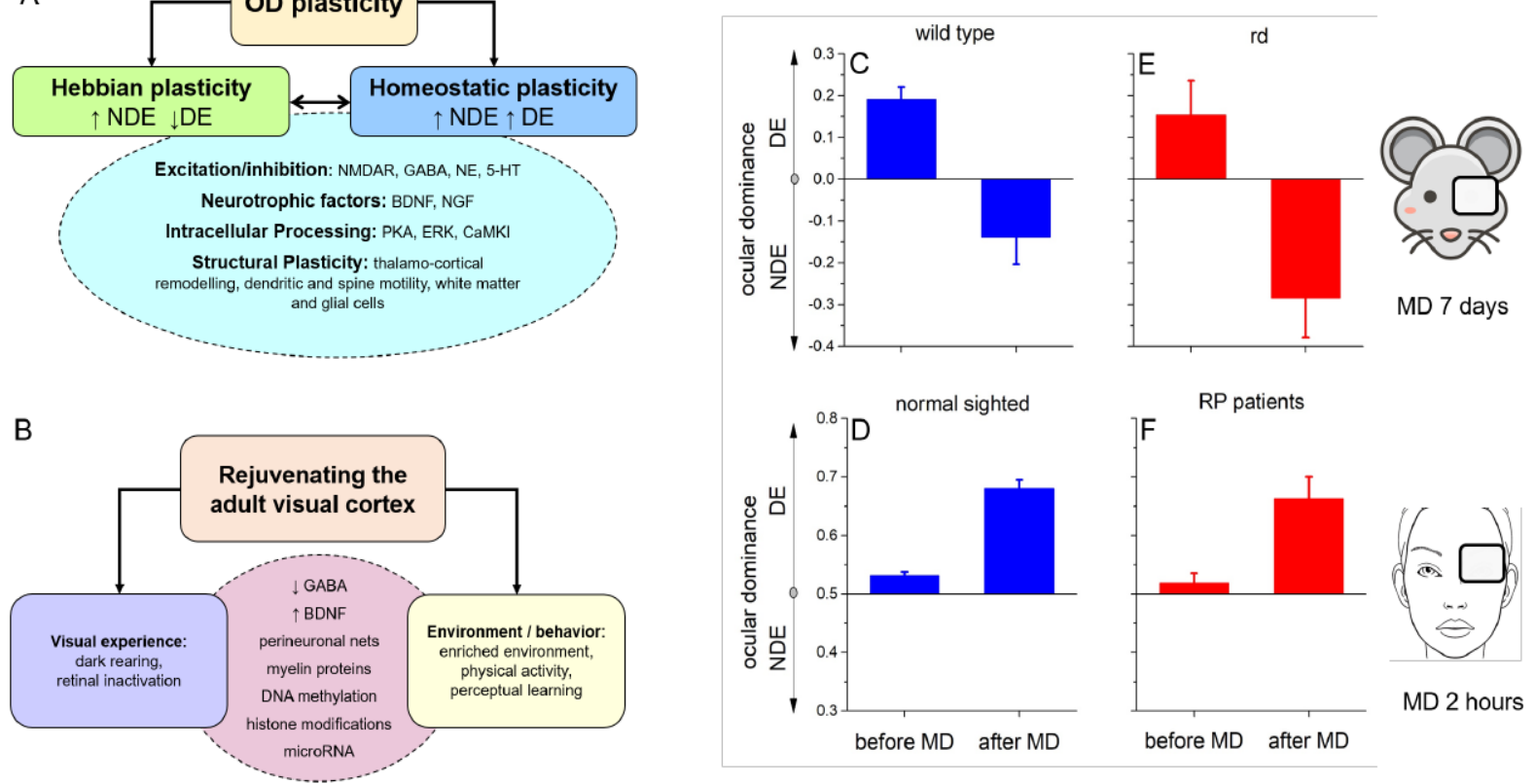

Figure 1. Ocular dominance plasticity in health and sickness. (A) Diagram of the neural mechanisms underlying Ocular Dominance (OD) plasticity observed after Monocular Deprivation (MD) in animal models. Acronyms: $D E=$ Deprived Eye, $\mathrm{NDE}=$ Non-Deprived Eye, NMDAR=N-methyl-D-aspartate receptor, GABA=Gamma aminobutyric acid, $\mathrm{NE}=$ norepinephrine, $5-\mathrm{HT}=$ serotonin, $\mathrm{BDNF}=$ Brain-derived neurotrophic factor, NGF=Nerve Growth Factor; PKA=Protein Kinase A, ERK=Extracellular Receptor Kinase, CaMKI=Calmodulin-dependent Kinase I. (B) Diagram of the strategies to reopen OD plasticity in adulthood and underlying neural mechanisms. (C,D) Ocular dominance index in wild-type (C) and rd10 (D) mice before and after 7 days of MD. Molecular deprivation resulted in a strong OD shift toward the open eye in both wild-type and rd mice. Data replotted from Begenisic et al., 2020. (E,F) Effect of short-term (2h) monocular deprivation in adult normalsighted humans $(E)$ and RP patients $(F)$ : perceptual ocular dominance (measured by means of binocular rivalry) unexpectedly shifts in favour of the deprived eye after MD. RP patients show a response to short-term monocular deprivation similar to normal-sighted participants, indicating preserved short-term visual plasticity in RP. Data replotted from Lunghi et al., 2019b. 